Original Research Paper

\title{
Factors Affecting Sustainable Development of Agricultural Cooperatives in the Mekong River Delta, Vietnam
}

\author{
Ha Nguyen Hong \\ Department of Finance-Banking, Deputy of Economics and Law, Travinh University, Vietnam
}

Article history

Received: 03-08-2017

Revised: 26-09-2017

Accepted: 26-10-2017

Email: honghaicbtv@yahoo.com.vn

\section{Introduction}

The Cooperative Law of Vietnam was launched in March 1996 and officially came into effect on January 1, 1997, creating a legal corridor and motive for cooperative development in various forms, and many different areas of the economy, especially agriculture and handicrafts. Co-operatives play an important role in the socio-economic development of Vietnam in general and in TraVinh province in particular: Creating jobs, supporting rural communities, creating tools for farmers, artisans, workers of all occupations, disadvantaged groups in society to improve their level, capacity, voice and position, social cohesion and harmony, etc., especially the context of economic integration and globalization today. Seeing that importance, the Party and State are always concerned about the development of cooperatives; In particular, the Resolution of the IXth National Party Congress affirmed "Developing cooperative and cooperative economy is a very important issue in the socio-economic development strategy." In particular, on July1st, 2013, the amended and supplemented Cooperative Law is considered to be a milestone marking the change in the organization of the collective economy, of which the cooperative is the key. The change in the nature of the 2012 Cooperative Law compared to the 2003 Cooperative Law will help the cooperatives grow to a new height.
According to the objective of the 5th Central Resolution on "Renovation, Development and Enhancement of Efficiency of Collective Economy", concrete contents in each aspect such as organizational restructuring, congress Cooperative members, accounting books, deductions for setting up funds, production and business plans and principles of organization and operation under the cooperative law.

The Mekong River Delta has a natural area of about 3.96 million hectares, of which agricultural land area is about 3.21 million hectares. The biggest advantage of this area is the production of rice, fruit trees and aquaculture, in which rice is not only food supply, ensuring national food security but it also provides rice for export. However, agricultural production in the region still has many shortcomings such as individual, small, and scattered production; link the "four houses" in the weak value chain; "output" for agro products is more difficult, frequent occurrence of bumper crops, but loss of price.

In addition, due to small scale production, when there is a great demand for purchasing, people cannot meet, hindering the application of modern science and technology achievements to production, impulsing the grows of agricultural production force. Therefore, the development of cooperatives in agriculture will help overcome these shortcomings.

The total number of cooperatives in the Mekong River Delta in by 2016 is 1,752 . Of which, there are 1,091 agricultural cooperatives, accounting for $62.3 \%$ by Table 1 . 
Table 1. Number of cooperatives in the Mekong River Delta in 2016 Unit: cooperative

\begin{tabular}{|c|c|c|c|c|c|c|c|c|c|c|}
\hline $\begin{array}{l}\text { Numerica } \\
\text { order }\end{array}$ & Provinces & Agri & Trade-service & Transport & Construction & Handicraft & $\begin{array}{l}\text { Credit } \\
\text { Fund }\end{array}$ & $\begin{array}{l}\text { Electricity } \\
\text { /water }\end{array}$ & Environment & Total \\
\hline 1 & An Giang & 98 & 0 & 20 & 0 & 7 & 24 & 0 & 0 & 149 \\
\hline 2 & ĐongThap & 171 & 2 & 7 & 1 & 6 & 17 & 0 & 1 & 205 \\
\hline 3 & Bac Lieu & 46 & 5 & 9 & 5 & 3 & 7 & 0 & 6 & 81 \\
\hline 4 & Ben Tre & 12 & 5 & 6 & 4 & 3 & 7 & 0 & 7 & 44 \\
\hline 5 & Can Tho & 51 & 7 & 29 & 33 & 9 & 8 & 0 & 2 & 139 \\
\hline 6 & HauGiang & 150 & 7 & 5 & 38 & 14 & 0 & 0 & 0 & 214 \\
\hline 7 & KienGiang & 200 & 1 & 8 & 5 & 5 & 22 & 0 & 0 & 241 \\
\hline 8 & TienGiang & 45 & 9 & 11 & 4 & 14 & 16 & 0 & 0 & 99 \\
\hline 9 & Long An & 55 & 1 & 17 & 3 & 3 & 19 & 0 & 0 & 98 \\
\hline 10 & SocTrang & 86 & 3 & 3 & 5 & 6 & 12 & 0 & 0 & 115 \\
\hline 11 & TraVinh & 41 & 1 & 7 & 18 & 7 & 16 & 3 & 1 & 94 \\
\hline 12 & Vinh Long & 25 & 7 & 12 & 17 & 23 & 4 & 0 & 0 & 88 \\
\hline \multirow[t]{2}{*}{13} & Ca Mau & 111 & 20 & 19 & 17 & 16 & 2 & 0 & 0 & 185 \\
\hline & Total & 1,091 & 68 & 153 & 150 & 116 & 154 & 3 & 17 & 1,752 \\
\hline
\end{tabular}

(Source: Vietnam Cooperative Alliance)

Developing cooperatives in agriculture aims to efficiently exploit the resources from agriculture, facilitating the process of industrialization and modernization of agriculture and rural areas in the Mekong River delta. Developing cooperatives facilitates the efficient exploitation of resources from agriculture as inputs and services for agricultural production, which is provided in time, sufficiently and quality ensuring; Production is carried out in the direction of concentration, facilitating the improvement of production efficiency. Cooperative development in agriculture facilitates the acceleration of new rural construction in the Mekong River Delta. One of the criteria of new rural communes is to have cooperative groups, or cooperatives to work effectively. The cooperatives also play the role of creating links between farmer households, improving economic efficiency in production, participating in the construction of rural infrastructure and environmental protection. The effective operation of the cooperative contributes to the consumption of products and helping farmers feel calm in production. This is a channel to mobilize resources promoting agricultural economic restructuring in the direction of commodity production, career development and income raising for farmers. In addition, agricultural cooperatives also play the role of organizing the reception of state support to farmers. However, agricultural cooperatives still have many limitations: (i) The activities of agricultural co-operatives have weaknesses in internal resources (capital, assets, co-operation, cohesion, management staff, services), still not linked to market supply and consumption of products yet, especially agricultural cooperatives newly established in the field of agriculture; (ii) The scope of the operation of the agricultural cooperative is still small in terms of management capacity, capital - assets and production and business aspects. Therefore, the level of support to cooperative members is limited, the efficiency of production and business is low, contributing to local socio-economic is not much; (iii) $30 \%$ of agricultural cooperatives show weakness in organization and operation not complying with the principle of Cooperative Law; $46 \%$ of the cooperative stopped or just formal existed; Not linking the input market for production, output for product consumption, product quality is not identical, not stable, so the competitiveness is weak; (V) Cooperative activities are formal, individual members, some households have not seen the benefits of cooperatives (Son, 2012).

These constraints and weaknesses have hampered the development and performance of the Mekong River Delta agricultural cooperatives. Facing with that situation, the research on sustainable development of agricultural cooperatives is very necessary and urgent.

\section{Theoretical Foundations and Research Methodology}

\section{Theoretical Foundations and Analytical Frameworks}

According to the Law of Cooperatives 2012, the cooperative is a collective economic organization, coownership, legal entity, founded by at least 07 members voluntarily and mutually support each other in production and business activity, creating jobs to meet the general needs of members, on the basis of selfcontrol, self-responsibility, equality and democracy in cooperative management.

Cooperative is a type of business organization. In order to survive and develop in a market economy, cooperatives must ensure the basic elements of a business organization: Finance, technology, human resources and knowledge for business administration. In addition to those basic factors, the cooperative is a social organization, which is different from other types of businesses that help the members. Cooperatives were established from the requirement of household economic development, supporting the development of household economy. Thus, for sustainable development, cooperatives in the development process depend on many factors.

According to Imagawa (2000), experience in the development of Japanese agricultural cooperatives and studies indicate that the Japanese Cooperative is a positive 
factor contributing significantly to the economic development and social stability. The cooperative should strengthen the management and business support guidelines for member cooperatives and planning. Thuvachote (2006) stresses that the development and provision of products, insurance programs and information networks should meet the needs of members. Also, it is important to organize courses and workshops on management and education for member cooperatives and Export-import of consumer good, etc. (Ibrahim Ngah, 2014).

According to Nguyen (2010), the number of operation years of agricultural co-operatives has positively influenced the profitability of agricultural cooperatives, which means that long-term cooperatives will have better performance. However, there is a view that long-time agricultural cooperatives are affected by older agricultural cooperative models leading to limited performance (Nguyen, 2008b). In order to ensure the cooperative sustainable development, the capital and labor factor are two important factors that determine the effectiveness of the cooperative's activities, promoting the production and business activities of the cooperative. According to Nguyen (2014), the cooperatives have high charter capital and business capital, the number of labor force more will bring higher profits. In addition, association with the input business is very important because when the cooperative linked with the input enterprises will create conditions for members to buy input materials for production and business at cheaper prices than the non-affiliated stores.

As a result, cooperative members are also advised by technical consultants on the use of more efficient input material (Quoc-Nhan et al., 2012). According to Nguyen (2008b), the role of state policy is very important, contributing greatly to the success and sustainable development of the cooperative. The State issued policies to assist cooperatives in the process of building and development through tax exemption, reduction, land allocation, land lease.

Cooperatives were established and functioned as the representative of individuals and households when consuming products. Co-operatives can directly sell products to consumers, can mediate between producers and traders by signing sales contracts or directly signing export contracts (Phan-Huy, 2009). One issue raised for the development of co-operatives is the lack of production facilities, the ability to invest in fixed assets of cooperatives is limited, not meet the demand for production materials to support for production and business of cooperative members. This discourages members' trust in the cooperative. With this situation, cooperatives find it difficult in production and business activities and support members (Nguyen, 2008a).

\section{Research Methodology}

\section{Method of Data Collection}

The figures used in the article are primary data collected from a questionnaire survey. The survey was conducted from April to December 2016 with the interview of 80 agricultural cooperatives in 03 provinces of TraVinh, SocTrang and Ben Tre. The cooperative selected the interview form based on the list of agricultural cooperatives in TraVinh, Ben Tre and SocTrang provinces.

\section{Methods of Data Analysis}

Study on the use of multivariable regression of inheritance and development from the studies of Abdulai and CroleRees (2001) Dinh (2009), Nguyen (2010). For sustainable development, agricultural cooperatives depend on aa number of factors, specifically the model as follows:

$$
Y i=\beta 0+\beta 1 X-1 i+\beta 2 X 2 i+\ldots+\beta 9 X 9 i+u i
$$

Of which: $Y$ variable is the annual income of cooperative (million VND). The $X$ variables are explained in detail in the Table 2 .

Table 2. A description of the independent variables that affect the profitability of the cooperative

\begin{tabular}{|c|c|c|c|c|}
\hline No & Name of variable & Definition of variable & $\begin{array}{l}\text { Expectation of } \\
\text { base sign }\end{array}$ & $\begin{array}{l}\text { Basic of } \\
\text { selecting variable }\end{array}$ \\
\hline 1 & Years of operation (X1) & Years of operation (year) & $+/-$ & $\begin{array}{l}\text { Nguyen (2010) } \\
\text { Nguyen (2008a) }\end{array}$ \\
\hline 2 & Chartered capital (X2) & Chartered capital (million vnd) & + & Nguyen (2014) \\
\hline 3 & Total number of employee (X3) & Total number of employees (persons) & + & Nguyen (2014) \\
\hline 4 & Business capital (X4) & Business capital (million VND) & + & Nguyen (2014) \\
\hline 5 & Link to business input (X5) & $\begin{array}{l}\text { The dummy variable, the cooperative is } \\
\text { with the input business that receives the } \\
\text { value } 1 \text {, otherwise returns the value } 0\end{array}$ & + & $\begin{array}{l}\text { Quoc-Nhan et al. } \\
\text { (2012) }\end{array}$ \\
\hline 6 & Tax reduction policy $(\mathrm{X} 6)$ & $\begin{array}{l}\text { Grade } 9 \text { is in ascending order, } 1 \text { the } \\
\text { lowest, and } 9 \text { the highest }\end{array}$ & + & Nguyen (2008b) \\
\hline 7 & $\begin{array}{l}\text { Policy on land allocation, } \\
\text { land lease (X7) }\end{array}$ & $\begin{array}{l}\text { Grade } 9 \text { is in ascending order, } 1 \text { the lowest, } \\
\text { and } 9 \text { the highest }\end{array}$ & + & Nguyen (2008a) \\
\hline 8 & Consumer product (X8) & $\begin{array}{l}\text { The dummy variable, the co-operative has the } \\
\text { product of the member receiving the value } 1 \text {, } \\
\text { otherwise the value is } 0\end{array}$ & + & Phan-Huy (2009) \\
\hline 9 & Fixed assets (X9) & Fixed assets (VND million) & + & Nguyen (2008b) \\
\hline
\end{tabular}




\section{Results and Discussion}

\section{Facts on the Factors Affecting the Performance of Cooperatives}

Fact surveys show that agricultural cooperatives operate on average 11 years, the highest up to 28 years. As such, agricultural cooperatives in the area have been operating for a long time. This has both advantages and disadvantages; in particular, the perennial agricultural cooperatives experience in operating the cooperative is better but is greatly influenced by the old cooperative model, which limits the development of the cooperative. Due to the advantage of the number of years of operation, the cooperatives in the provinces have business capital as well as the chartered capital is relatively large. When participating in a cooperative, the cooperative members contribute their capital to the cooperative and will be divided according to the share of the cooperative based on the principle of equality, mutual benefit and democracy.

With survey data, the average agricultural cooperative has 24 employees; the lowest is 3 and the largest 150 employees. In general, the current number of laborers of the cooperative meets the needs of production and business of the cooperative. However, the level of management of the cooperative is weak and short of experience, unfamiliar with the business management under the market mechanism. This also causes the quality constraints and the attractiveness of the agricultural cooperative model. Many cooperatives still lack people of technical qualification. Therefore, in order to do well in technical services, they need support and assistance from the state.

The state always plays an important role in supporting, nurturing and developing the cooperative movement. Experience of countries with strong cooperative movements, such as the Federal Republic of Germany, Japan, Korea, etc., show that the role of the state is very important in creating the environment and conditions for the cooperative development. Data from Table 3 shows the state's interest in the development of cooperatives. However, the level of beneficiaries of the cooperative from state policies such as the policy of tax exemption, land allocation, and land lease was only averaged (5/9) and low (3/9) Evaluation of the cooperative.

In addition to the above factors, the lively condition of the cooperative is to care for inputs and outputs for the cooperative. In fact, only $25.5 \%$ of cooperatives have linked with input enterprises to provide input services to cooperative members, $37.7 \%$ of cooperatives have consumption products for cooperative members. Thus, many cooperatives in the area have not expressed their role to members. Many cooperatives have not oriented towards the members in the production process, not represented the members while consuming products, have not built and protected the brand. These things make the income of the cooperative in general and the members in particular are limited. The cooperatives are still moving from the old cooperative model to the new cooperative model, the business practices are also heavily influenced by the old mechanism, not actively and dynamically in the search for input market and output for cooperatives.

\section{Factors Affecting the Performance of Cooperatives}

As presented in the research methodology, the article uses multivariable regression to analyze the factors affecting business performance of agricultural cooperatives. Table 4 shows that the $\mathrm{X} 3$ variable is significant with a $90 \%$ confidence level; Variables $\mathrm{X} 5, \mathrm{X} 8$ are significant with $95 \%$ confidence; The X4 variable makes sense with $99 \%$ confidence. Verification of the suitability of the model, multicollinearity $(\mathrm{Vif}<10)$, self-correlation, and variance have been shown to point out no offense. Provided that other factors are remained.

Total labor (X3): This independent variable has negatively correlation with cooperative profits at a significance level of $\alpha=10 \%$. Business capital (x4): This independent variable has a positive coefficient. This coincides with the results of research by Nguyen (2014). Business capital is a very important factor in production, increased business capital will be proportional to the income of cooperatives.

Link to input business (X5): This variable correlates well with the profitability of the cooperative at a significance level of $\alpha=5 \%$. As expected initially, when the cooperative is linked to the input business, the profits of the cooperative will be higher than in the none of affiliation with the input business. Product consumption for members (X8): This variable correlates well with cooperative income at significance level of $\alpha=5 \%$. This is correlated with the results of research by PhanHuy (2009), when the cooperative has product consumption for members; the income of cooperatives will be higher. Factors of operating years (X1), charter capital (X2), tax exemption (X6), and land allocation policy (X7) are not statistically significant. In other words, with the survey data, there is insufficient evidence to show that these factors affect the income of the agricultural cooperative.

\section{Some Solutions and Suggestions for Sustainable Development Policy of Agricultural Cooperatives}

\section{Developing the Policy of Supporting Agricultural Cooperatives}

Continue to support and expand available policies (technology, breeding, input, and output). Policies must be specific and implemented promptly; some policies should be prioritized for members of agricultural cooperatives than individuals to attract people to participate in cooperatives. When the policy is set, information should be provided promptly and widely so that the beneficiaries can capture the information. 
Table 3. Factors affecting the performance of agricultural cooperatives

\begin{tabular}{|c|c|c|c|c|c|}
\hline Targets & $\begin{array}{l}\text { Number of } \\
\text { observations }\end{array}$ & Smallest & Medium & Biggest & $\begin{array}{l}\text { Standard } \\
\text { deviation }\end{array}$ \\
\hline Years of operation (year) & 80 & 1 & 11.000 & 28.0 & 7.000 \\
\hline Charter capital (VND million) & 80 & 13 & 1.076 & 6.8 & 1.213 \\
\hline Total number of employees (people) & 80 & 3 & 24.000 & 150.0 & 26.000 \\
\hline Business capital (VND million) & 80 & 32 & 6.828 & 45.2 & 11.708 \\
\hline Tax exemption policy (scale from 1 to 9 ) & 80 & 1 & 5.000 & 9.0 & 3.000 \\
\hline Policy on land allocation, land lease (scale from 1 to 9) & 80 & 1 & 3.000 & 9.0 & 2.000 \\
\hline Fixed assets (VND million) & 80 & 3 & 388.000 & 1.7 & 466.000 \\
\hline
\end{tabular}

Source: Survey group, 2016

Table 4. Results of regression model estimation

\begin{tabular}{llll}
\hline Affected factors & Estimated coefficient & Value T & VIF \\
\hline Constant (C) & $2.502,707$ & 1,450 & 0,819 \\
Years of operation (X1) & 51,961 & $-1,443$ & 4,131 \\
Chartered capital (X2) & $-0,294$ & $-2,190^{*}$ & 1,870 \\
Total number of employees (X3) & $-53,963$ & $3,193 * * *$ & 2,714 \\
Business capital (X4-) & 0,082 & $2,261^{* *}$ & 2,428 \\
Link to business input (X5) & $1.275,632$ & 1,173 & 1,271 \\
Tax reduction policy (X6) & 91,491 & 0,927 & 1,517 \\
Policy on land allocation, land lease (X7) & 105,443 & 1,146 \\
Consumer products (X8) & $1.924,789$ & $3,205^{* *}$ & \\
$\mathrm{R}^{2}: 0,759$ & & & \\
ANOVA: F: 4,326** & & & \\
d=1,973 & & & \\
Spearman correlation coefficient has sig. From 0.161 to 0.868 & & & \\
\hline
\end{tabular}

Note: ${ }^{*}, * *,{ }^{* *}$ are significant at the $\alpha$ level of $10 \%, 5 \%$ and $1 \%$ respectively.

Source: Survey Group, 2016

To adopt policies to support the investment and development of the agricultural cooperative model and then replicate the model. To implement the policy of open air mainly is to help difficult groups to operate in the early establishment (loan assistance, investment in equipment ...). To have a policy to help groups working in the same career link together, exchange experience or share the output contracts and must develop strategies for the development of different types of agricultural cooperatives. There should be policies to attract enterprises to supply raw materials for cooperatives.

\section{Organizing the Training and Team}

It is vital for the Agricultural Cooperative Management Board to have Regular training, capacity testing and retraining. The state needs to have payroll for the director or vice president of co-operatives to support co-operative development in two years, with priority should be given to agricultural co-operatives. There should be remuneration for staff working in cooperatives.

Set up payroll for staff of district, city, commune, ward and township officials in charge of cooperatives in order to understand and supervise the situation of cooperatives so as to have timely supports. The support and advisory units for the cooperative need to have professional staff and stable positions. It is important to improve capacity for cooperative alliance staff, commune and district officials working in consultancy, care and support to develop agricultural cooperatives. There should be emulation and commendation for individuals and collectives whose ideas and practices have successfully applied to help cooperatives develop.

\section{About Capital Policy}

There should be policies to encourage commercial bank loans based on feasible and effective production and business plans of cooperatives so as to provide them with preferential loans in line with plans through credit guarantee funds when the cooperative does not qualify mortgage, pledge.

It is important to support the deferred payment policy of machinery and equipment for production for agricultural cooperatives. Credit unions, group incentives or unsecured credit for cooperatives are bound to be subject to state inspection and supervision. Provide regular operating budget to the board of directors, team leader for the first year. Provide financial support to organize visits, exchanges and learning experiences. Increase budget to ensure regular and continuous training for co-operatives and investment in building models for 3-5 cooperatives/year.

\section{Linking Outputs for Agricultural Cooperatives}

Cooperative members, production members have not followed a technical process and not up to market requirements, so the product is not uniform. Therefore, 
the State supports the linking input-output market, create stable output, and build the raw material area. In addition, purchasing companies buy quality products at higher prices than conventional products.

Study the classification of product quality and have an effective investment plan. For example, assessing which products can be exported, sold in supermarkets developing, products that cannot be developed should not be invested for development.

Support for branding and market information. Cooperatives must have specific business goals, ideas and then set up teams. When establishing a team, there must be a plan for development and specific activities to develop in a sustainable way.

\section{Limitations of Research and Future Research}

This study was based on the survey of only 80 agricultural cooperatives and 3 provinces in the Mekong delta that did not adequately reflect the activities of agricultural cooperatives in Vietnam. Therefore, the research is conducted only in agricultural cooperatives without reflecting all types of cooperatives in Vietnam. In addition, the number of survey samples is low and implemented over a period of one year. There is a need for studies on the type of co-operative in Vietnam to see the status and development prospects of cooperatives in Vietnam as well as in other countries.

\section{Acknowledgement}

This research was carried out with the support of Viet Nam Cooperative Alliance (VCA), Tra Vinh province Cooperative Alliance, Soc Trang province Cooperative Alliance and Ben Tre province Cooperative Alliance. The Author sincerely thanks for the help of colleagues and the survey teams to support the success of this article.

\section{Ethics}

I undertake responsibility for this research, if any ethical of the issues arising later in relation to this manuscript, I take full responsibility from my research.

\section{References}

Abdulai, A. and A. CroleRees, 2001. Determinants of income diversification amongst rural households in Southern Mali. Food Policy, 26: 437-452.

Dinh, V.P., 2009. Some solutions to increase income of midland households in Phu Tho province. J. Econom. Development.

Imagawa, N., 2000. Introduction to Agricultural Cooperatives Japan, Agricultural Publishing House.

Ibrahim, N., 2014. Exploring rural transformation in Malaysia: A case of rice cultivation area in Sabak Bernam.

Nguyen, D., 2008a. Cooperative development policy in Vietnam. J. Econom. Forecasting, 11: 19-21.

Nguyen, M.H., 2008b. New model cooperative. J. Econom. Forecasting, 2: 38-40.

Nguyen, V.T., 2014. Solutions to improve the performance of agricultural cooperatives in GiaRai district, Bac Lieu province. Bac Lieu University, Bac Lieu province.

Nguyen, V.V.A., 2010. Analysis of factors affecting the robust development of typical agricultural cooperatives in a Giang and TienGiang. PhD thesis, Can Tho University.

Phan-Huy, D., 2009. Promoting the role of cooperatives in the consumption of agricultural products. Communist Rev., 29: 31-33.

Thuvachote, S., 2006. Agricultural Cooperatives in Thailand: Innovations and Opportunities in 21st Century. 1st Edn., Food and Fertilizer Technology Center, Taipei, pp: 15.

Son, 2012. A comprehensive survey of cooperative economy in Tra Vinh province in 2011. MDI Institute, Can Tho University and Co-operative Alliance of Tra Vinh.

Quoc-Nhan, T., D.V. Hoang and D.C. Nguyen, 2012. Analysis of benefits from new farming cooperatives brought to people: Case study of cooperative Long Tuyen, BinhThuy district, Can Tho city. Scientific J. Can Tho University, No. 22b: 283-293. 